\title{
KAJIAN PERBANDINGAN TEPUNG TERIGU (Triticum aestivum) DENGAN TEPUNG JEWAWUT (Setaria italica) TERHADAP KARAKTERISTIK ROTI MANIS
}

\author{
Dede Zainal Arif \\ Wisnu Cahyadi \\ Adinda Sarah Firdhausa \\ Program Studi Teknologi Pangan, Fakultas Teknik, Universitas Pasundan, J1. Dr.Setiabudi No 93, Bandung, 40153, \\ Indonesia \\ E-mail : dedezainalarief@unpas.ac.id
}

\begin{abstract}
Abstrak
Tujuan penelitian ini untuk mengurangi penggunaan tepung terigu dengan penambahan tepung jewawut pada produk roti manis. Manfaat dari penelitian ini antara lain dapat meningkatkan nilai ekonomis dari jewawut, dan dapat memanfaatkan hasil pangan lokal. Metode penelitian yang digunakan adalah Regresi Linier Sederhana. Pembuatan roti manis dengan penentuan batas minimum tepung terigu dengan perbandingan 5: 5, 6: 4, 7:3, 8: 2, dan 9: 1 . Roti yang telah diproduksi dilakukan pengujian terhadap volume dan pengembangan porositas. Langkah selanjutnya yaitu penentuan formulasi pembuatan roti manis dengan perbandingan tepung terigu dan tepung jewawut yaitu 7:3, 7,5:2,5 dan 8: 2. Hasil penelitian pendahuluan menunjukkan kadar gluten $1,06 \%$, dan sifat amilografi tepung jewawut yaitu suhu gelatinisasi $85,4^{\circ} \mathrm{C}$, viskositas puncak $660 \mathrm{Cp}$, viskositas breakdown $2210 \mathrm{Cp}$ dan kemunduran kekentalan $1550 \mathrm{Cp}$. Sifat amilografi tepung terigu adalah suhu gelatinisasi $89,3^{\circ} \mathrm{C}$, viskositas puncak $530 \mathrm{Cp}$, viskositas breakdown $645 \mathrm{Cp}$ dan viskositas setback 115 Cp. Batasan minimum rasio tepung terigu dan tepung jewawut sebesar 7: 3 untuk membuat roti manis. Roti manis yang dipilih digunakan perbandingan tepung terigu dan tepung jewawut adalah 8: 2 karena disukai oleh panelis berdasarkan uji organoleptik. Roti manis yang terpilih memiliki kadar air 19,22\%, kadar protein 7,48\%, kadar karbohidrat 57,37\%, kadar lemak 2,2\%, serat makanan 3,54\% dan 1,91 mg/100 gram kalsium serta total energi 279,2 kkal yang memenuhi 13,96\% kecukupan gizi per hari. Sedangkan roti manis kontrol mengandung 22,49\% kadar air, kadar protein 8,59\%, kadar karbohidrat 52,17\%, kadar lemak 2,50\%, serat makanan sebesar 1,63\% dan 1,33 mg/100 gram kalsium serta total energi 265,54 kkal yang memenuhi 13,277 \% kecukupan gizi per hari.
\end{abstract}

\begin{abstract}
The objective of this study was reduced the use of wheat flour with adding of millet flour on sweet bread products. The benefits of this research was increased the economic value of millet, and could increase local products. Research method that is used was a simple linear regression. Production of sweet bread began by determine the minimum limit of wheat flour with the ratio of 5: 5, 6: 4, 7: 3, 8:2, and 9: 1. Bread that has been produced was tested by volume and porosity. The next step was the determination of sweet bread formulations by comparing wheat flour and millet flour ratio 7: 3, 7.5: 2.5 and 8: 2. The preliminary program results show gluten content $1.06 \%$, and the amylographic properties of millet flour was $85.4^{\circ} \mathrm{C}$ the gelatinization temperatured, peak viscosity was $660 \mathrm{Cp}$, the breakdown viscosity was $2210 \mathrm{Cp}$ and the setback viscosity was $1550 \mathrm{Cp}$. The amylographic properties of wheat flour are gelatinization temperature was $89.3^{\circ} \mathrm{C}$, peak viscosity was $530 \mathrm{Cp}$, breakdown viscosity was $645 \mathrm{Cp}$ and setback viscosity was $115 \mathrm{Cp}$. The minimum limit of the ratio of flour and millet flour was 7: 3 for making sweet bread. The sweet bread chosen by wheat flour and millet flour was 8: 2 because it was liked by the panelists based on the organoleptic test. Selected sweet bread has a moisture content of 19.22\%, protein content of $7.48 \%$, carbohydrate content of $57.37 \%$, fat content of $2.2 \%$, dietary fiber $3.54 \%$ and $1.91 \mathrm{mg} / 100$ grams of calcium and total energy of $279.2 \mathrm{kcal}$ which satisfies $13.96 \%$ of nutrient adequacy per day. While control sweet bread contains $22.49 \%$ air content, $8.59 \%$ protein content, carbohydrate content $52.17 \%, 2.50 \%$ fat content, dietary fiber as much as $1.63 \%$ and $1.33 \mathrm{mg} / 100$ gram grams and total energy of $265.54 \mathrm{kcal}$ which fulfills $13.277 \%$ of nutrition per day.
\end{abstract}

Keywords: Wheat Flour, Millet Flour, Sweet Bread. 


\section{Pendahuluan}

Dewasa ini, tepung terigu sudah menyebar merata di setiap lapisan masyarakat sebagai salah satu bahan pokok pengolahan berbagai macam makanan, salah satunya roti. Roti adalah sejenis makanan dengan bahan dasar utama yaitu tepung dan air yang difermentasikan oleh ragi, tetapi ada juga yang tidak menggunakan ragi. Bahan baku yang digunakan untuk pembuatan roti adalah tepung terigu. Tepung terigu merupakan bahan hasil olahan dari golongan nabati yaitu gandum. Gandum merupakan jenis biji-bijian serealia yang paling banyak jumlahnya dibandingkan dengan biji-bijian hasil olahan bahan pangan lainnya. (Dina, 2012).

Menurut Laoli (2017), ketergantungan Indonesia terhadap gandum semakin meningkat karena semakin banyaknya produk olahan tepung terigu sebagai bahan makanan pokok. Menyebabkan terjadi peningkatan impor gandum ke Indonesia setiap tahunnya. Pada tahun 2017, diperkirakan kebutuhan gandum nasional mencapai 8,79 ton. Tanpa disadari impor gandum dalam jumlah yang fantastis tersebut dapat mengancam stabilitas perekonomian negara.

Selama ini terigu di Indonesia sebagai bahan baku pembuatan produk bakery, salah satunya roti. Menurut Astawan (2009), roti umumnya dibuat dari tepung terigu hard wheat (terigu protein tinggi). Tepung terigu hard wheat mampu menyerap air dalam jumlah besar, dapat mencapai konsistensi adonan yang tepat, memiliki elastisitas yang baik untuk menghasilkan roti dengan remah halus, tekstur lembut, volume besar, dan mengandung $12-13 \%$ protein.

Menurut Fhirman (2015), protein dalam gandum yang berbentuk gluten berperan dalam menentukan kekenyalan makanan. Hal tersebut menjadi pokok pembuatan produk seperti mie, kue dan roti. Gluten diperlukan untuk menahan gas hasil fermentasi pada pembuatan roti sehingga roti dapat mengembang.

Menurut Alamendah (2015), berbagai studi mengungkapkan kandungan nutrisi jewawut lebih baik dibanding jagung dan beras. Kandungan gizi yang dipunyainya meliputi karbohidrat $84,2 \%$, protein $10,7 \%$, lemak $3,3 \%$, serat $1,4 \%$, Ca $37 \mathrm{mg}$, Fe 6,2 mg, vitamin C 2,5, vitamin B1 0,48, dan vitamin B2 0,14.

Jewawut berpotensi untuk dikembangkan sebagai pengganti karbohidrat lain. Salah satunya dapat dijadikan sebagai pengganti tepung terigu karena selain karbohidratnya lebih tinggi dibanding gandum, juga kandungan proteinnya sama serta jewawut juga mengandung protein gluten.

Maksud dari penelitian ini adalah untuk mengetahui perbandingan yang tepat antara tepung terigu dan tepung jewawut agar menghasilkan roti manis yang berkualitas baik.
Tujuan dari penelitian ini adalah untuk mengetahui apakah penggunaan tepung terigu dapat digantikan oleh tepung-tepungan lain salah satunya tepung jewawut, agar penggunaan tepung terigu dapat dikurangi sedikit demi sedikit.

Manfaat yang diharapkan dari penelitian ini yaitu dapat meningkatkan nilai ekonomis dari jewawut, dapat memanfaatkan hasil pangan lokal agar ketergantungan terhadap hasil pangan impor sedikit-sedikit dapat dikurangi, untuk mengenalkan potensi pangan lokal khususnya jewawut kepada masyarakat serta untuk mencapai kedaulatan pangan di Indonesia.

Roti adalah makanan yang dibuat dengan mencampurkan tepung terigu, air dan bahan penyusun lainnya menjadi adonan yang kemudian difermentasi dengan ragi roti dan dipanggang (Syamsir, 2014).

Karakteristik roti yang baik meliputi volume pengembangan yang cukup, warna kulit roti coklat keemasan dan bagian dalamnya (crumb) cerah, pori-pori seragam dengan dinding pori yang tipis, teksturnya halus dan lembut serta tidak bersifat remah, serta memiliki aroma khas roti yang harum.

Berdasarkan kerangka pemikiran, maka dapat disusun hipotesa sebagai berikut:

Diduga perbandingan tepung terigu dengan tepung jewawut berpengaruh terhadap karakteristik roti manis.

\section{Bahan dan Metodologi Penelitian}

Bahan-bahan percobaan yang digunakan dalam penelitian yaitu jewawut jenis Foxtail millet, tepung terigu berprotein tinggi, ragi fermipan, air minum dalam kemasan, gula pasir, telur ayam, mentega, garam, susu bubuk dan bread improver.

Bahan-bahan untuk uji gluten yaitu air, $\mathrm{NaCl} 1 \%$. Analisis kadar protein yaitu $\mathrm{H}_{2} \mathrm{SO}_{4}$, aquades, $\mathrm{NaOH}$ $50 \%$, granul $\mathrm{Zn}, \mathrm{HCl} 0,1 \mathrm{~N}$, indikator metil merah, etanol $95 \%, \mathrm{NaOH} 0,1 \mathrm{~N}$. Untuk kadar karbohidrat yaitu $\mathrm{Na}_{2} \mathrm{CO}_{3}$ anhidrat, asam sitrat monohidrat, $\mathrm{CuSO}_{4} \cdot 5 \mathrm{H}_{2} \mathrm{O}$, $\mathrm{HCl} 3 \%, \mathrm{NaOH} 30 \%, \mathrm{CH}_{3} \mathrm{COOH} 3 \%$, larutan Luff Schoorl, KI 20\%, $\mathrm{H}_{2} \mathrm{SO}_{4} 25 \%, \mathrm{Na}_{2} \mathrm{~S}_{2} \mathrm{O}_{3} \quad 0,1 \mathrm{~N}$, dan amilum $1 \%$. Untuk kadar serat pangan yaitu petroleum eter, natrium fosfat $\mathrm{pH} 6$, termamyl, $\mathrm{HCl} 4 \mathrm{M}$, pepsin, pankreatin, etanol 95\%, aseton dan etanol 78\%. Untuk analisis kadar lemak yaitu $\mathrm{n}$ heksan. Sedangkan untuk analisis kadar kalsium yaitu Aquades, amonium oksalat jenuh, asam asetat, indikator metil merah, $\mathrm{H}_{2} \mathrm{SO}_{4}$, $\mathrm{KMnO}_{4} 0,1 \mathrm{~N}$.

\section{Penelitian Pendahuluan}

Penelitian pendahuluan yang dilakukan yaitu pembuatan tepung jewawut serta analisis bahan baku meliputi pengujian kadar gluten dari tepung jewawut dan 
pengujian sifat amilografi tepung jewawut dan tepung terigu.

\section{Penelitian Utama Tahap I}

Penelitian utama tahap I dilakukan untuk mengetahui batas minimal penggunaan tepung terigu untuk pembuatan roti sehingga menghasilkan roti yang memiliki kualitas baik, yang dinilai berdasarkan volume pengembangan adonan roti dan porositas dari roti.

\section{Penelitian Utama Tahap II}

Setelah didapatkan batas minimal penggunaan tepung terigu dari penelitian utama tahap I, kemudian dilakukan penentuan perbandingan formulasi yang tepat yang terdiri dari 3 taraf dengan perbedaan 0,5 . Setelah ditentukan perbandingannya, dilanjutkan dengan proses pembuatan roti manis. Roti manis kemudian dilakukan pengujian organoleptik untuk menentukan sampel terpilih untuk diuji kandungan nutrisinya serta total angka kecukupan gizi.

Metode penelitian yang digunakan adalah Regresi Linier Sederhana dengan menggunakan rumus $\mathrm{Y}=\mathrm{a}+$ bX.

Keterangan :

$\mathrm{X}=$ Variabel Bebas

$\mathrm{a}, \mathrm{b}=$ Parameter Regresi

$\mathrm{Y}=$ variabel Terikat

Tabel 1. Pendataan Nilai Variabel

\begin{tabular}{|c|c|}
\hline Variabel bebas $(\mathbf{X})$ & Variabel terikat $(\mathbf{Y})$ \\
\hline $\mathrm{X}_{1}$ & $\mathrm{Y}_{1}$ \\
$\mathrm{X}_{2}$ & $\mathrm{Y}_{2}$ \\
$\mathrm{X}_{3}$ & $\mathrm{Y}_{3}$ \\
\hline
\end{tabular}

Keterangan :

$\mathrm{X}_{1}, \mathrm{X}_{2}, \mathrm{X}_{3}=$ Perbandingan I, II, III

$\mathrm{Y}_{1}, \mathrm{Y}_{2}, \mathrm{Y}_{3}=$ Respon terhadap $\mathrm{X}_{1}$

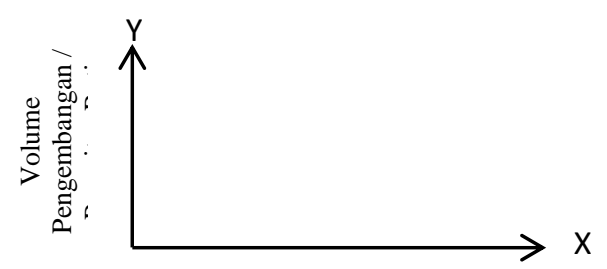

Perbandingan Tepung Terigu dan Tepung Jewawut

Gambar 1. Grafik Contoh Hubungan Linier
Rancangan respon yang dilakukan meliputi respon organoleptik dengan atribut warna, rasa, aroma, tekstur dan keseragaman pori.

Tabel 2. Skala Nilai Uji Kesukaan (Uji Hedonik)

\begin{tabular}{|c|c|}
\hline Skala Hedonik & Skala Numerik \\
\hline Amat sangat suka & 6 \\
\hline Sangat suka & 5 \\
\hline Suka & 4 \\
\hline Tidak suka & 3 \\
\hline Sangat tidak suka & 2 \\
\hline $\begin{array}{c}\text { Amat sangat tidak } \\
\text { suka }\end{array}$ & 1 \\
\hline
\end{tabular}

Respon kimia meliputi analisis kadar protein menggunakan metode semi-mikro Kjeldahl (SNI 012891-1992), kadar karbohidrat menggunakan metode Luff Schoorl (SNI 01-2891-1992), kadar lemak menggunakan metode soxhlet (SNI 01-2891-1992), kadar air menggunakan metode gravimetri (AOAC, 2005), kadar kalsium serta kadar serat pangan (AOAC, 1995). Respon fisik meliputi pengukuran volume pengembangan dan porositas roti.

\section{Hasil dan Pembahasan}

Penelitian Pendahuluan

1. Pembuatan Tepung Jewawut

Pertama biji jewawut dicuci dan dibersihkan dari kontaminan, kemudian biji jewawut direbus agar terjadi pregelatinisasi dan juga agar mudah dipisahkan dari kulitnya. Setelah itu, jewawut dikeringkan dengan menggunakan tunnel dryer dengan suhu $60^{\circ} \mathrm{C}$ selama 6-8 jam sampai kadar air mencapai 5\%. Jewawut yang telah dikeringkan, dilakukan tempering agar suhunya sama dengan suhu ruang dan ketika di lakukan penghancuran tidak terjadi bumping. Jewawut kemudian dilakukan penghancuran dengan menggunakan alat penepung dengan ukuran 80 mesh untuk mendapatkan partikel yang lebih kecil dan memudahkan proses pengayakan. Pengayakan bertujuan untuk menghasilkan ukuran partikel yang seragam serta untuk memisahkan antara tepung dengan kulitnya. Pada proses ini menggunakan ayakan berukuran 80 mesh. Penyangraian dilakukan selama 15-20 menit agar kadar air dalam tepung berkurang.

Tabel 3. Hasil Pengujian Sifat Amilografi Tepung

\begin{tabular}{|c|c|c|c|c|c|c|c|}
\hline \multirow{2}{*}{ Sampel } & \multicolumn{2}{|c|}{ Gelatinisasi } & \multicolumn{3}{c|}{ Viskositas Puncak } & \multicolumn{3}{c|}{ Viskositas (Cp) } \\
\cline { 2 - 8 } & Waktu (menit) & Suhu $\left({ }^{\circ} \mathrm{C}\right)$ & Waktu (menit) & Suhu $\left({ }^{\circ} \mathrm{C}\right)$ & Visc $(\mathrm{Cp})$ & Dingin 50 ${ }^{\circ} \mathrm{C}$ & Balik \\
\hline $\begin{array}{c}\text { Tepung } \\
\text { Terigu }\end{array}$ & 17 & 89,3 & 22 & 94,6 & 530,0 & 645,0 & 115,0 \\
\hline $\begin{array}{c}\text { Tepung } \\
\text { Jewawut }\end{array}$ & 16 & 85,4 & 21 & 93,3 & 660,0 & 2210,0 & 1550,0 \\
\hline
\end{tabular}




\section{Grafik Hubungan Viskositas Tepung dengan Suhu Gelatinisasi}
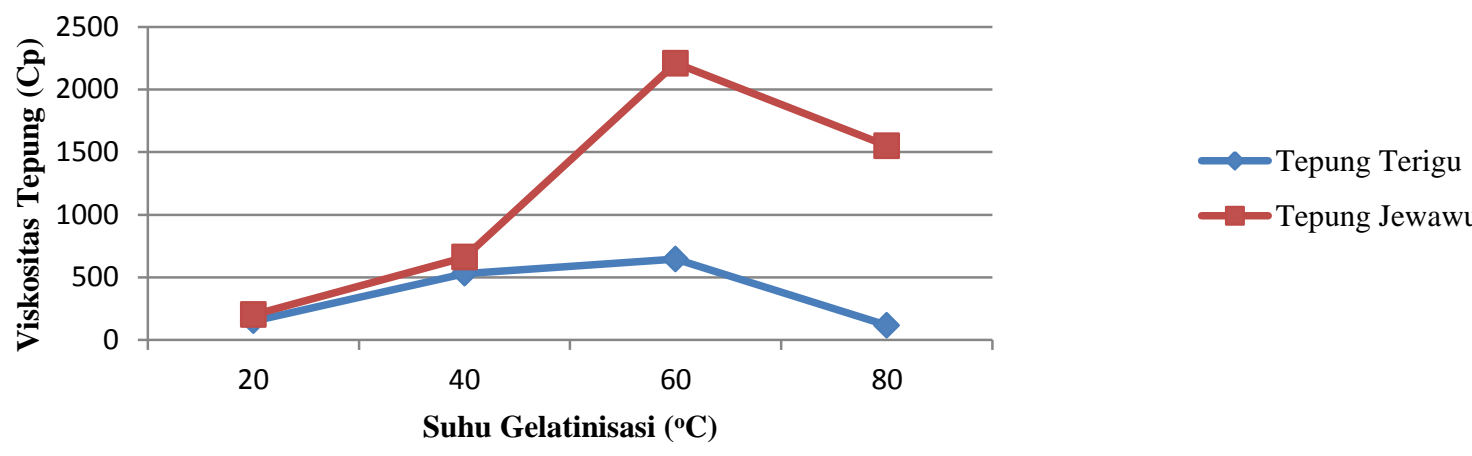

$\longrightarrow$ Tepung Jewawut

Gambar 2. Grafik Hubungan Viskositas Tepung dengan Suhu Gelatinisasi.

Dari data di atas, dapat disimpulkan bahwa :

\section{Suhu Gelatinisasi}

Berdasarkan data hasil sifat pasting properties tepung jewawut, suhu gelatinisasi pada tepung jewawut lebih rendah dibandingkan dengan tepung terigu, yaitu $85,4^{\circ} \mathrm{C}$ sedangkan terigu berada di suhu $89,3^{\circ} \mathrm{C}$. Suhu gelatinisasi yang lebih rendah menunjukkan bahwa hidrasi atau pengikatan air lebih mudah terjadi, sehingga pada suhu yang lebih rendah, granula pati sudah mulai tergelatinisasi. Selain itu, keberadaan amilosa juga menjadi penentu tinggi rendahnya suhu gelatinisasi. Jika dilihat dari suhu gelatinisasi tepung jewawut yang lebih rendah, maka dapat disimpulkan bahwa kadar amilosa tepung jewawut lebih tinggi dibandingkan dengan kadar amilosa tepung terigu.

\section{Viskositas Puncak dan Suhu Viskositas Puncak}

Berdasarkan data hasil pengujian diperoleh viskositas puncak dari tepung terigu sebesar $530.0 \mathrm{Cp}$ dengan suhu viskositas puncak $94,6^{\circ} \mathrm{C}$ dan tepung jewawut sebesar 660.0 $\mathrm{Cp}$ dengan suhu viskositas puncak $93,3^{\circ} \mathrm{C}$. Viskositas puncak merupakan viskositas tertinggi yang terukur selama proses pemanasan. Suhu saat tercapainya viskositas puncak disebut sebagai suhu viskositas puncak. Dari hasil diatas, dapat disimpulkan bahwa tepung jewawut mengalamin pembengkakan granula yang lebih tinggi dibandingkan dengan tepung terigu. Hal ini sesuai dengan pernyataan Ulyarti (1997), bahwa viskositas puncak berkaitan erat dengan pembengkakan granula dimana semakin tinggi pembengkakan granula maka semakin tinggi pula viskositas puncaknya.

\section{Viskositas Breakdown}

Berdasarkan hasil pengujian diperoleh nilai VB dari tepung terigu yaitu $645 \mathrm{Cp}$ dan tepung jewawut memiliki nilai VB $2210 \mathrm{Cp}$. Pengadukan yang kontinu menyebabkan granula pati yang rapuh akan pecah sehingga viskositas turun secara tajam. Dengan nilai VB yang lebih kecil, tepung terigu cenderung lebih stabil dibandingkan tepung jewawut karena memiliki kemampuan yang lebih baik dalam mempertahankan viskositasnya selama pemanasan. Viskositas breakdown menggambarkan tingkat kestabilan pasta pati terhadap proses pemanasan. Viskositas breakdown (VB) ini diperoleh sebagai selisih antara viskositas puncak dengan viskositas pasta pati setelah holding pada suhu $95^{\circ} \mathrm{C}$ pada tahap pemanasan (Aryee et al., 2003).

\section{Viskositas Setback}

Berdasarkan hasil pengujian, tepung jewawut memiliki nilai viskositas setback lebih tinggi yaitu 1550 $\mathrm{Cp}$ dibandingkan dengan tepung terigu yaitu hanya 115 Cp. Hal ini menunjukan bahwa tepung jewawut memiliki kecenderungan untuk beretrogradasi lebih besar dibandingkan dengan tepung terigu. Menurut Copeland et al, (2009) nilai setback sebagai peningkatan viskositas dari nilai minimum hingga nilai akhir viskositas selama pengukuran. Dengan demikian nilai viskositas setback merupakan selisih antara viskositas akhir pendinginan dengan viskositas awal pendinginan. Viskositas setback menggambarkan stabilitas gel dan tingkat kecenderungan proses retrogradasi dan sineresis pasta pati. Retrogradasi merupakan proses kristalisasi kembali pati yang telah mengalami gelatinisasi (Winarno, 2002).

\section{Penelitian Utama Tahap I}

Penentuan Batas Minimal Tepung Terigu

Penentuan batas minimal tepung terigu digunakan sebagai dasar untuk menentukan perbandingan tepung pada pembuatan roti di penelitian utama. Pada percobaan ini batas-batas yang telah ditentukan yaitu dengan perbandingan tepung terigu dan tepung jewawut sebesar 5:5, 6:4, 7:3, 8:2 dan 9:1. Hasil penilaian dilihat dari volume pengembangan dan porositas roti, seperti yang disajikan pada data berikut ini : 
1. Volume Pengembangan (\%)

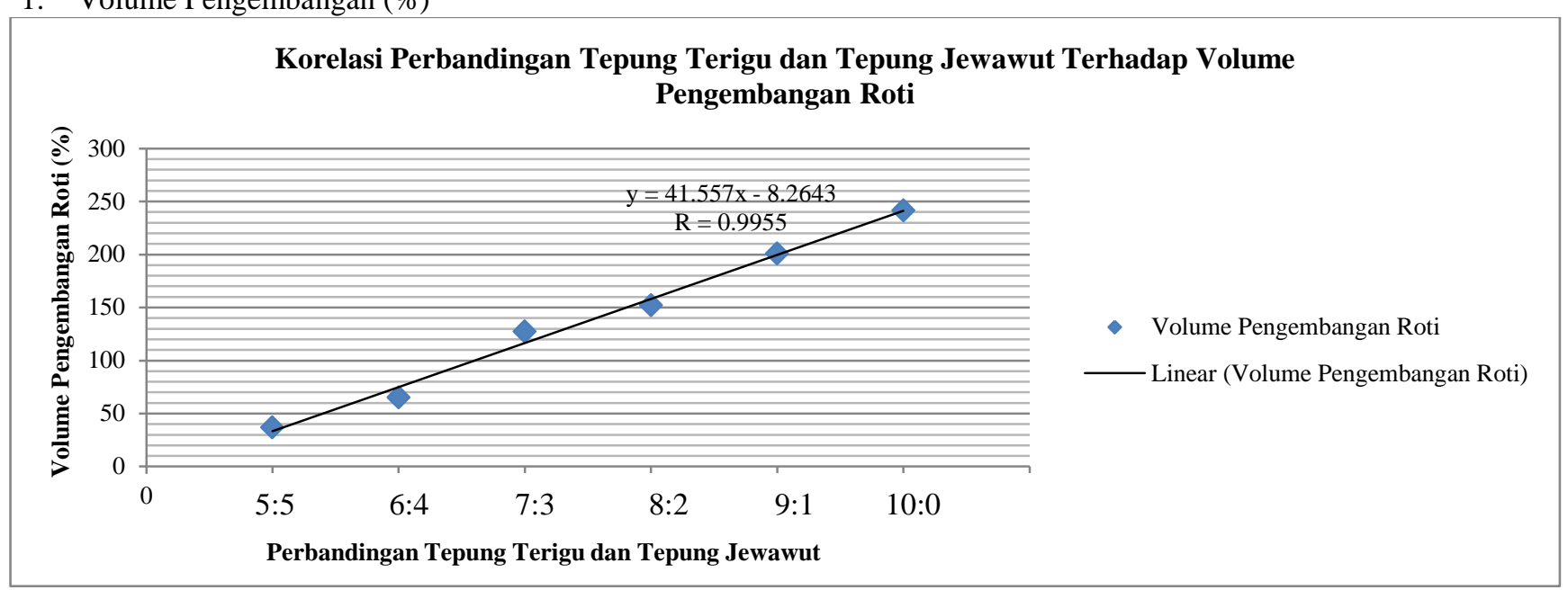

Gambar 3. Grafik Korelasi Perbandingan Tepung Terigu dan Tepung Jewawut Terhadap Volume Pengembangan

Berdasarkan grafik diatas, dapat diketahui bahwa antara formulasi tepung terigu dan $\%$ volume pengembangan memiliki korelasi positif yang sangat kuat. Hal ini ditunjukkan dengan nilai r yang mendekati 1 yaitu sebesar 0.9955 yang artinya memiliki hubungan yang earah. Semakin tinggi nilai $\mathrm{x}$ maka nilai y juga semakin meningkat, serta nilai $r$ yang mendekati 1 yang berarti berkorelasi sangat kuat, yang berarti jumlah tepung terigu yang digunakan sangat berpengaruh terhadap volume pengembangan karena keberadaan gluten di dalamnya.

Menurut Aprodu dan Banu (2014), peningkatan jumlah tepung jewawut pada formulasi adonan roti dapat menurunkan kadar protein serta kadar gluten, yang menyebabkan kemampuan menahan gas pada adonan menjadi berkurang. Gluten berfungsi untuk mempertahankan gas untuk mendapatkan volume yang diinginkan dan tekstur dalam sistem adonan. Glutenin dan gliadin adalah fraksi utama gluten. Sementara gliadin menyediakan viskositas dan extensibility adonan, glutenin bertanggung jawab untuk sifat elastis dan kohesif adonan sehingga gas $\mathrm{CO}_{2}$ hasil fermentasi dari ragi selama proses fermentasi dan pemanggangan tertahan oleh lapisan gluten yang elastis yang menyebabkan volume pengembangan roti meningkat.

\section{Porositas Roti}

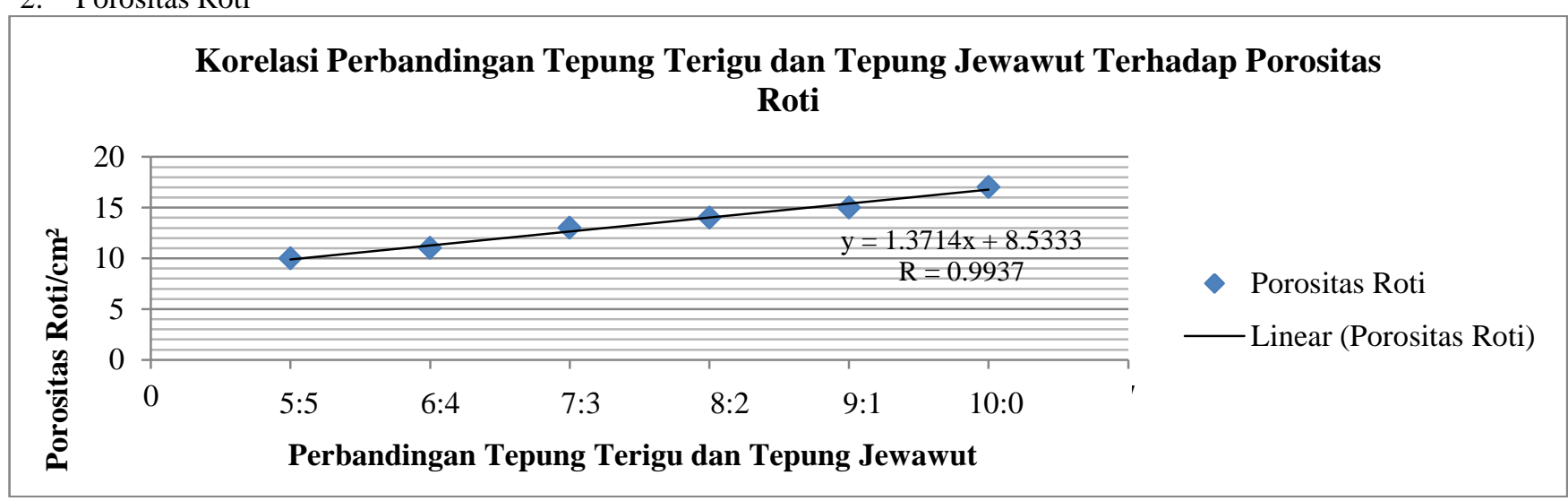

Gambar 4. Grafik Korelasi Antara Formulasi Tepung Terigu Terhadap Porositas Roti

Berdasarkan grafik diatas, dapat diketahui bahwa antara formulasi tepung terigu dengan porositas roti memiliki korelasi positif yang sangat kuat. Hal ini ditunjukkan dengan nilai $r$ yang mendekati 1yaitu sebesar 0.9937 yang artinya memiliki hubungan yang searah.
Semakin tinggi nilai $\mathrm{x}$ maka nilai $\mathrm{y}$ juga semakin meningkat, serta nilai $\mathrm{r}$ yang mendekati 1 yang berarti berkorelasi sangat kuat. Yang berarti jumlah tepung terigu yang digunakan sangat berpengaruh terhadap porositas roti. 
Hasil yang diperoleh menunjukan bahwa dengan adanya bahan baku yang berbeda memberikan pengaruh nyata terhadap jumlah pori-pori yang di hasilkan, dimana semakin banyak penambahan tepung jewawut maka jumlah porositas semakin berkurang dan tidak beraturan. Menurut Sullivan et al (2011), jumlah pori-pori pada roti merupakan jumlah $\mathrm{CO}_{2}$ yang terperangkap dalam adonan selama poses proofing, sementara ukuran pori-pori pada roti diindikasikan ukuran dari gas-gas $\mathrm{CO}_{2}$. Jumlah dan ukuran pori-pori berkaitan erat dengan tingkat pengembangan dan tekstur roti. Jumlah pori, pada roti yang bermutu baik diantaranya ditandai dengan penyebaran pori-pori yang merata, pori-pori merupakan lubang atau sel udara yang terdapat pada roti dan terbentuk selama proses fermentasi atau pembakaran.
Hasil pengamatan ini menunjukan bahwa jumlah porositas sangat dipengaruhi oleh jenis tepung yang digunakan (Kartiwan dkk, 2007).

Berdasarkan hasil diatas, maka dipilihlah perbandingan penggunaan tepung terigu dan tepung jewawut yaitu 7:3 karena pada perbandingan tersebut adonan sudah mengembang 2 kali lipat dari volume awal dan mulai menunjukkan karakteristik fisik dari roti. Hal ini juga sesuai dengan pernyataan Chhavi dan Sarita (2012), bahwa batas penerimaan roti yang menggunakan campuran tepung jewawut sebanyak 30\%, karena penggunaan tepung jewawut melebihi $30 \%$ penerimaan terhadap roti semakin rendah. Kenampakan roti manis dari berbagai macam perbandingan dapat dilihat pada Gambar 5.

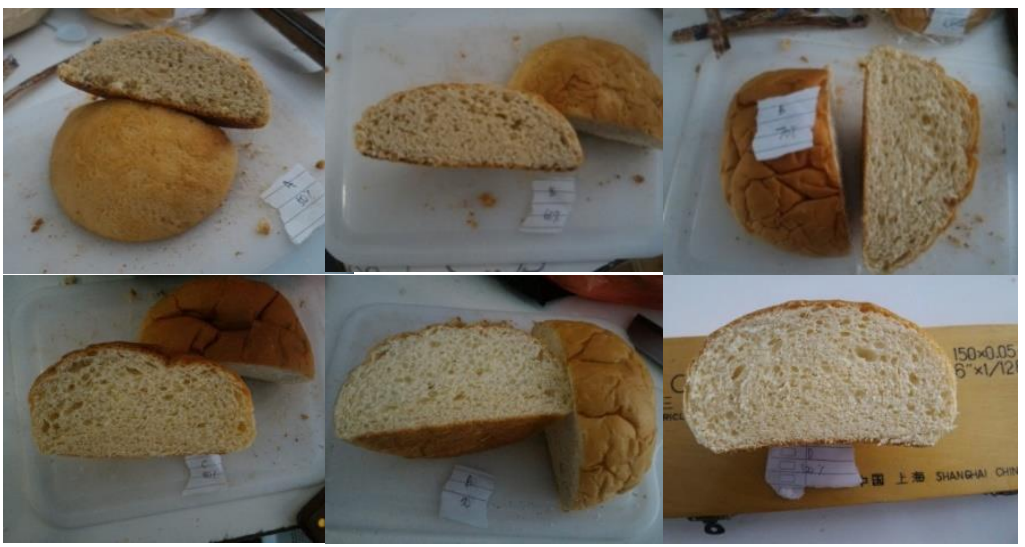

Gambar 5. Kenampakan Roti dengan Berbagai Macam Perbandingan Tepung Terigu

\section{Penelitian Utama Tahap II}

Pada proses penentuan perbandingan tepung terigu dan tepung jewawut, setelah menetapkan batas minimal tepung, kemudian dilakukan uji organoleptik terhadap 3 taraf perbandingan tepung terigu dan tepung jewawut, yaitu sampel dengan perbandingan tepung terigu dan tepung jewawut 7:3, 7,5:2,5 dan 8:2. Pengujian organoleptik yang dilakukan berupa uji hedonik yang dilihat dari kesukaan panelis dari berbagai macam atribut seperti warna, aroma, rasa, tekstur dan keseragaman pori.

\section{Atribut Warna}

Berdasarkan hasil penilaian yang di berikan panelis terhadap warna roti manis yang menggunakan tepung terigu dan tepung jewawut, menyatakan bahwa warna roti manis yang disukai adalah roti manis dengan perbandingan 8:2 karena memiliki nilai rata-rata yang lebih besar. Penambahan tepung jewawut mempengaruhi warna roti manis yang dibuat. Warna roti manis yang diberi campuran tepung jewawut menjadi agak kecoklatan. Hal ini disebabkan oleh pigmen betakaroten dan komponen flavonoid seperti glikosilvitesin, glikosiloritin, alkali labil dan asam ferulat dari jewawut
(Leder, 2004). Hasil uji lanjut Duncan pada warna roti manis menunjukan bahwa dengan adanya perbedaan perlakuan dari bahan dasar tepung terigu dan tepung jewawut, memberikan pengaruh nyata terhadap warna dari roti yang di hasilkan.

Hasil uji organoleptik dengan metode skala hedonik terhadap warna roti dapat dilihat pada tabel 4 .

Tabel 4. Nilai rata-rata uji organoleptik tingkat kesukaan sensorik terhadap Warna Roti manis

\begin{tabular}{|c|c|c|}
\hline $\begin{array}{c}\text { Tepung } \\
\text { Terigu:Tepung } \\
\text { Jewawut }\end{array}$ & $\begin{array}{c}\text { Rata-rata } \\
\text { Warna }\end{array}$ & $\begin{array}{c}\text { Taraf Nyata } \\
5 \%\end{array}$ \\
\hline $\mathbf{7 , 5 : 2 , 5}$ & 4.35 & $\mathrm{a}$ \\
\hline $\mathbf{7 : 3}$ & 4.45 & $\mathrm{a}$ \\
\hline $\mathbf{8 : 2}$ & 4.98 & $\mathrm{~b}$ \\
\hline
\end{tabular}

\section{Atribut Aroma}

Hasil uji organoleptik dengan metode skala hedonik terhadap aroma roti yang menggunakan tepung terigu dan tepung jewawut dapat dilihat pada tabel 5 .

Tabel 5. Nilai rata-rata uji organoleptik tingkat kesukaan sensorik terhadap Aroma Roti manis 


\begin{tabular}{|c|c|c|}
\hline $\begin{array}{c}\text { Tepung } \\
\text { Terigu:Tepung } \\
\text { Jewawut }\end{array}$ & $\begin{array}{c}\text { Rata-rata } \\
\text { Aroma }\end{array}$ & $\begin{array}{c}\text { Taraf Nyata } \\
5 \%\end{array}$ \\
\hline $\mathbf{7 , 5 : 2 , 5}$ & 4.22 & $\mathrm{a}$ \\
\hline $\mathbf{7 : 3}$ & 4.28 & $\mathrm{a}$ \\
\hline $\mathbf{8 : 2}$ & 4.30 & $\mathrm{a}$ \\
\hline
\end{tabular}

Keterangan $=$ nilai rata-rata yang diikuti huruf yang berbeda maka berbeda nyata pada taraf 5\%.

Berdasarkan hasil penilaian yang di berikan panelis terhadap roti manis dengan menggunakan tepung terigu dan tepung jewawut menyatakan bahwa aroma roti manis yang paling disukai yaitu roti manis dengan perbandingan 8:2. Hasil uji lanjut Duncan menunjukan bahwa perbedaan perbandingan tepung terigu dan tepung jewawut tidak memberikan pengaruh nyata terhadap aroma yang di hasilkan, tetapi perbandingan tepung 8:2 memiliki nilai yang lebih besar dibandingkan dengan 7,5:2,5 dan 7:3. Penambahan tepung jewawut yang lebih besar menyebabkan aroma pada roti manis menjadi kurang disukai. Hal ini karena tepung jewawut memiliki aroma khas yang cukup kuat, tidak seperti tepung terigu yang memiliki aroma yang lebih tawar, sehingga semakin banyak penambahan tepung jewawut maka semakin menurunkan nilai daya terima panelis terhadap aroma roti manis. Hal ini diduga karena pada jewawut terdapat komponen goitrogen yang diidentifikasi sebagai penyebab off-odor dan dikarakterisasi juga sebagai flavor mousy ((Leder, 2004).

\section{Atribut Rasa}

Hasil uji organoleptik dengan metode skala hedonik terhadap rasa roti yang menggunakan tepung terigu dan tepung jewawut dapat dilihat pada tabel 6 .

Tabel 6. Nilai rata-rata uji organoleptik tingkat kesukaan sensorik terhadap Rasa Roti manis

\begin{tabular}{|c|c|c|}
\hline $\begin{array}{c}\text { Tepung } \\
\text { Terigu:Tepung } \\
\text { Jewawut }\end{array}$ & $\begin{array}{c}\text { Rata-rata } \\
\text { Rasa }\end{array}$ & $\begin{array}{c}\text { Taraf } \\
\text { Nyata 5\% }\end{array}$ \\
\hline $\mathbf{7 : 3}$ & 3.87 & $\mathrm{a}$ \\
\hline $\mathbf{7 , 5 : 2 , 5}$ & 3.95 & $\mathrm{a}$ \\
\hline $\mathbf{8 : 2}$ & 4.37 & $\mathrm{a}$ \\
\hline
\end{tabular}

Keterangan $=$ nilai rata-rata yang diikuti huruf yang berbeda maka berbeda nyata pada taraf 5\%.

Berdasarkan hasil penilaian yang di berikan panelis terhadap roti manis dengan menggunakan tepung terigu dan tepung jewawut menyatakan bahwa rasa roti manis yang paling disukai yaitu roti manis dengan perbandingan 8:2. Hasil uji lanjut Duncan menunjukan bahwa perbedaan perbandingan tepung terigu dan tepung jewawut tidak memberikan pengaruh nyata terhadap rasa yang di hasilkan, tetapi perbandingan tepung 8:2 memiliki nilai yang lebih besar dibandingkan dengan
7,5:2,5 dan 7:3. Penambahan tepung jewawut yang lebih banyak menyebabkan daya penerimaan terhadap rasa roti manis semakin berkurang. Semakin rendah persentase tepung terigu maka semakin tidak disukai.

\section{Atribut Tekstur}

Hasil uji organoleptik dengan metode skala hedonik terhadap tekstur roti yang menggunakan tepung terigu dan tepung jewawut dapat dilihat pada tabel 7 .

Tabel 7. Nilai rata-rata uji organoleptik tingkat kesukaan sensorik terhadap Tekstur Roti manis

\begin{tabular}{|c|c|c|}
\hline $\begin{array}{c}\text { Tepung } \\
\text { Terigu:Tepung } \\
\text { Jewawut }\end{array}$ & $\begin{array}{c}\text { Rata-rata } \\
\text { Tekstur }\end{array}$ & $\begin{array}{c}\text { Taraf } \\
\text { Nyata 5\% }\end{array}$ \\
\hline $\mathbf{7 : 3}$ & 3.75 & $\mathrm{a}$ \\
\hline $\mathbf{7 , 5 : 2 , 5}$ & 3.85 & $\mathrm{a} \mathrm{b}$ \\
\hline $\mathbf{8 : 2}$ & 4.33 & $\mathrm{~b}$ \\
\hline
\end{tabular}

Keterangan $=$ nilai rata-rata yang diikuti huruf yang berbeda maka berbeda nyata pada taraf $5 \%$.

Berdasarkan hasil penilaian yang di berikan panelis terhadap roti manis dengan menggunakan tepung terigu dan tepung jewawut menyatakan bahwa tekstur roti manis yang paling disukai yaitu roti manis dengan perbandingan 8:2. Hasil uji lanjut Duncan menunjukan bahwa perbedaan perbandingan tepung terigu dan tepung jewawut memberikan pengaruh nyata terhadap tekstur yang di hasilkan, tetapi perbandingan tepung 8:2 memiliki nilai yang lebih besar dibandingkan dengan 7,5:2,5 dan 7:3. Hal ini karena semakin banyak penambahan tepung jewawut maka tekstur roti akan semakin keras.

Menurut Hidayati (2013), tingkat kekerasan roti disebabkan oleh penurunan volume roti karena tingkat pengembangan yang menurun dan disebabkan kadar gluten yang berkurang sehingga gas yang dapat ditahan menurun. Hasil analisis uji kesukaan sensorik tekstur roti tepung jewawut menunjukkan adanya perbedaan daya terima tekstur pada roti manis yang dihasilkan, sehingga pada hasil uji lanjut Duncan menunjukan bahwa dengan adanya perbedaan perlakuan bahan dasar dari tepung terigu dan tepung jewawut memberikan pengaruh nyata terhadap tekstur roti tersebut. Pengaruh perbandingan tepung dalam pembuatan roti manis sangat berarti. Karena semakin banyak tepung jewawut yang digunakan akan menyebabkan tekstur roti semakin keras, tetapi sebaliknya semakin banyak penggunaan tepung terigu maka tekstur roti akan semakin empuk.

\section{Atribut Keseragaman Pori}

Hasil uji organoleptik dengan metode skala hedonik terhadap keseragaman pori roti yang menggunakan tepung terigu dan tepung jewawut dapat dilihat pada tabel 8 . 
Tabel 8. Nilai rata-rata uji organoleptik tingkat kesukaan sensorik terhadap keseragaman pori roti manis

\begin{tabular}{|c|c|c|}
\hline $\begin{array}{c}\text { Tepung } \\
\text { Terigu:Tepung } \\
\text { Jewawut }\end{array}$ & $\begin{array}{c}\text { Rata-rata } \\
\text { Keseragaman } \\
\text { Pori }\end{array}$ & $\begin{array}{c}\text { Taraf } \\
\text { Nyata 5\% }\end{array}$ \\
\hline $\mathbf{7 : 3}$ & 3.70 & a \\
\hline $\mathbf{7 , 5 : 2 , 5}$ & 4.18 & b c \\
\hline $\mathbf{8 : 2}$ & 4.20 & c \\
\hline
\end{tabular}

Keterangan $=$ nilai rata-rata yang diikuti huruf yang berbeda maka berbeda nyata pada taraf $5 \%$.

Berdasarkan hasil penilaian yang di berikan panelis terhadap roti manis dengan menggunakan tepung terigu dan tepung jewawut menyatakan bahwa keseragaman pori roti manis yang paling disukai yaitu roti manis dengan perbandingan 8:2. Hasil uji lanjut
Duncan menunjukan bahwa perbedaan perbandingan tepung terigu dan tepung jewawut terutama dengan perbandingan 7:3 dengan memberikan pengaruh nyata terhadap keseragaman pori yang di hasilkan, tetapi perbandingan tepung 8:2 memiliki nilai yang lebih besar dibandingkan dengan 7,5:2,5 dan 7:3. Semakin rendah penggunaan tepung terigu maka semakin tidak disukai karena pori-pori roti semakin kurang seragam dan tidak merata.

Berdasarkan perhitungan ANAVA, roti manis dengan perbandingan tepung terigu dan tepung jewawut 8:2 memiliki nilai lebih unggul dibandingkan 7:3 dan 7,5:2,5. Maka roti manis dengan perbandingan 8:2 ditetapkan sebagai sampel terpilih dari hasil pengujian organoleptik.

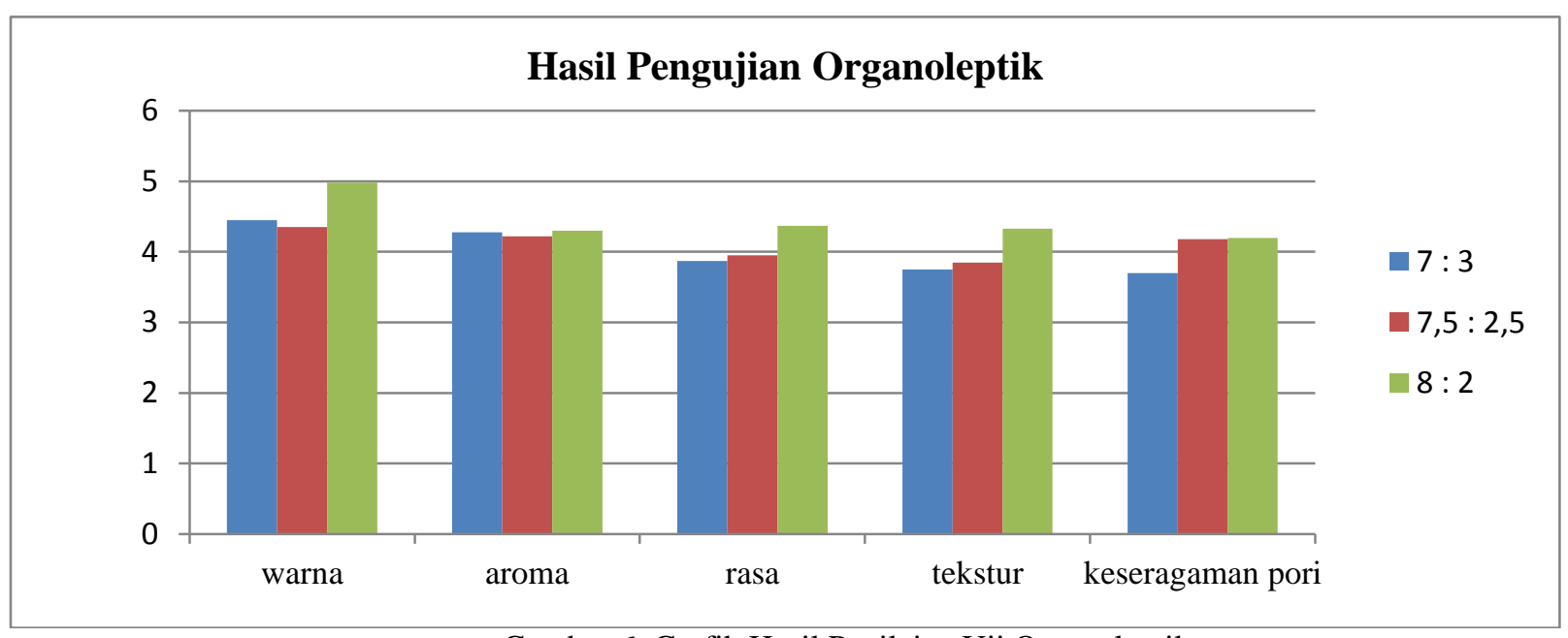

Gambar 6. Grafik Hasil Penilaian Uji Organoleptik

\section{Analisis Kandungan Nutrisi Pada Roti}

Tabel 9. Hasil Analisis Kandungan Nutrisi dari Produk

\begin{tabular}{|c|c|c|c|c|c|c|c|c|}
\hline Sampel & Kadar Air & $\begin{array}{c}\text { Kadar } \\
\text { Protein }\end{array}$ & $\begin{array}{c}\text { Kadar } \\
\text { Karbohidrat }\end{array}$ & $\begin{array}{c}\text { Kadar } \\
\text { Lemak }\end{array}$ & $\begin{array}{c}\text { Kadar } \\
\text { Serat } \\
\text { Pangan }\end{array}$ & Kadar Kalsium & $\begin{array}{c}\text { Kalori/Energi } \\
\text { Kkal) }\end{array}$ & $\begin{array}{c}\% \text { AKG } \\
\text { Roti A }\end{array}$ \\
\hline Roti B & $22.49 \%$ & $8.59 \%$ & $52.17 \%$ & $2.50 \%$ & $1.63 \%$ & $1.33 \mathrm{mg} / 100 \mathrm{~g}$ & 26,2 \\
\hline
\end{tabular}

Keterangan :

Roti $\mathrm{A}=$ Perbandingan Tepung Terigu dan Tepung Jewawut 8:2

Roti $\mathrm{B}=$ Perbandingan Tepung Terigu dan Tepung Jewawut 1:0
Setelah didapatkan sampel terpilih, maka selanjutnya dilakukan pengujian secara kimia yang meliputi kadar air, kadar karbohidrat, kadar lemak, kadar protein, kadar serat pangan dan kadar kalsium terhadap 
sampel terpilih yaitu dengan perbandingan tepung terigu dan tepung jewawut 8:2 dan juga sampel kontrol yang hanya menggunakan tepung terigu.

1. Kadar Air

Kadar air pada roti dengan perbandingan tepung terigu dan tepung jewawut 8:2 lebih rendah yaitu $19.22 \%$ dibandingkan dengan roti yang hanya menggunakan tepung terigu yaitu 22.49\%. Hal ini disebabkan kandungan gluten pada kedua tepung berbeda. Menurut Parker (2003), gluten merupakan protein tidak larut dalam air yang terkandung dalam tepung terigu yang bersifat hidrofilik sehingga dapat mengikat air. Semakin banyak kadar gluten dalam tepung, maka semakin besar pula kadar air yang berikatan dengan tepung yang dapat meningkatkan viskositas bahan.

\section{Kadar Protein}

Kadar protein pada roti dengan perbandingan tepung terigu dan tepung jewawut 8:2 lebih rendah yaitu $7.48 \%$ dibandingkan dengan roti yang hanya menggunakan tepung terigu yang mencapai $8.59 \%$. Kadar protein pada jewawut memang lebih rendah menurut Balitserealia (2004), yaitu sekitar 10,7\% sedangkan tepung terigu mencapai $12-14 \%$. Ada banyak faktor yang dapat mempengaruhi kadar protein pada produk. Selain kadar protein dari bahan baku awal, proses produksi juga dapat mempengaruhi kadar protein pada roti, salah satunya yaitu proses fermentasi.

Proses fermentasi pada roti menggunakan ragi Saccharomyces cereviciae. Ragi terdiri dari sejumlah kecil enzym, termasuk protease. Enzim protease juga dapat mempengaruhi karakteristik fisik ikatan gluten yang dihasilkan. Sedikit enzim protease dapat memecah beberapa ikatan peptida menghasilkan penurunan viskositas yang lebih cepat dari dispersi glutenin. Protease juga akan menghidrolisis molekul protein dalam bentuk yang lebih spesifik sehingga kadar protein awal pada bahan baku berpengaruh terhadap kadar protein pada produk.

\section{Kadar Karbohidrat}

Kadar karbohidrat pada roti dengan perbandingan tepung terigu dan tepung jewawut 8:2 lebih unggul yaitu $57.37 \%$ dibandingkan dengan roti yang hanya menggunakan tepung terigu yaitu $52.17 \%$. Jika dilihat dari kadar karbohidrat awal pada bahan baku, terjadi penurunan pada produk akhir. Hal ini dapat disebabkan oleh beberapa faktor, diantaranya pada saat proses produksi.

\section{Kadar Lemak}

Kadar lemak pada roti dengan perbandingan tepung terigu dan tepung jewawut 8:2 lebih rendah yaitu $2.2 \%$ dibandingkan dengan roti yang hanya menggunakan tepung terigu yaitu $2.50 \%$. hal ini dikarenakan adanya perbedaan kadar lemak awal dari masing-masing bahan baku, yang kemudian adanya penambahan lemak (mentega) pada proses pembuatan roti.

Menurut Koswara (2009), adanya lemak pada roti membantu mempertinggi rasa, memperkuat jaringan zat gluten, roti tidak cepat menjadi keras dan daging roti tidak lebih empuk sehingga dapat memperpanjang daya tahan simpan roti. Selain itu penambahan lemak menyebabkan nilai gizi dan rasa lezat roti bertambah.

\section{Kadar Serat Pangan}

Kadar serat pangan pada roti dengan perbandingan tepung terigu dan tepung jewawut 8:2 lebih tinggi yaitu $3.54 \%$ dibandingkan dengan roti yang hanya menggunakan tepung terigu yaitu $1,63 \%$. Jika dilihat dari hasil penelitian, maka penggunaan tepung jewawut dapat menaikan kadar serat pangan dalam produk. Kadar serat pada tepung jewawut lebih banyak daripada kadar serat tepung terigu karena proses pembuatan tepung yang berbeda menyebabkan kulit jewawut tidak benar-benar hancur sehingga serat dari tepung jewawut ini masih tinggi.

Serat pangan memiliki banyak manfaat bagi tubuh terutama dalam mencegah berbagai penyakit, meskipun komponen ini belum dimasukkan sebagai zat gizi (Piliang dan Djojosoebagio, 1996). Makanan kaya serat juga dapat memperlambat proses penyerapan energi lebih lama. Hal itu disebabkan makanan kaya serat meningkatkan intensitas pengunyahan, memperlambat proses makan, dan menghambat laju pencernaan makanan. Akibatnya energi yang masuk dalam tubuh lebih efisien, sehingga tidak berubah menjadi lemak. Serat juga meningkatkan ekskresi lemak, sehingga dapat membantu mengurangi berat badan.

\section{Kadar Kalsium}

Kadar kalsium pada roti dengan perbandingan tepung terigu dan tepung jewawut 8:2 lebih tinggi yaitu $1.91 \mathrm{mg} / 100$ gram dibandingkan dengan roti yang hanya menggunakan tepung terigu yaitu $1.33 \mathrm{mg} / 100 \mathrm{gram}$. Hal ini karena kadar kalsium pada jewawut lebih unggul dibandingkan dengan tepung terigu. Penambahan tepung jewawut pada adonan juga menyebabkan kenaikan kadar kalsium pada produk.

\section{Perhitungan AKG}

Berdasarkan data pada tabel diatas, maka dapat diketahui jumlah energi total pada masing-masing sampel roti, yaitu 279,2 kkal/100gram untuk roti A dan 265,54 $\mathrm{kkal} / 100$ gram untuk roti B. Jika dilakukan perbandingan antara produk roti manis yang dibuat, maka roti dengan penambahan tepung jewawut dapat memenuhi 13,96\% angka kecukupan gizi perhari untuk manusia dewasa, sedangkan roti yang hanya menggunakan tepung terigu 
memiliki energi yang sedikit lebih rendah yaitu memenuhi 13,277\% angka kecukupan gizi perhari.

Berdasarkan penelitian yang telah dilakukan dapat diambil kesimpulan bahwa penambahan tepung jewawut berpengaruh terhadap karakteristik dari roti manis yang dihasilkan, serta batas maksimal penggunaan tepung jewawut yaitu $30 \%$. Setelah dilakukan uji organoleptik dengan perbandingan tepung terigu dan tepung jewawut $7: 3,7,5: 2,5$ dan 8:2, maka terpilihlah perbandingan $8: 2$ untuk tepung terigu dan tepung jewawut yang selanjutnya dilakukan analisis proksimat untuk menentukan angka kecukupan gizi dari produk. Hasilnya, roti manis dengan perbandingan tepung terigu dan tepung jewawut 8:2 memiliki keunggulan dari segi kadar karbohidrat, serat pangan, kalsium serta jumlah kalori dengan angka kecukupan gizi sebesar 13,96\%, sedangkan roti yang hanya menggunakan tepung terigu memiliki keunggulan dari segi kadar protein dan lemak serta memiliki angka kecukupan gizi sebesar 13,277\%.

\section{DAFTAR PUSTAKA}

1. Alamendah. 2015. Jewawut Tanaman Pangan yang Terabaikan. https://alamendah.org/2015/07/22/jewawut-tanamanpangan-yang-terabaikan/ . Diakses : 23 April 2017.

2. Aprodu, Iuliana dan Iuliana Banu. 2014. Rheological, Thermo-mechanical and Baking Properties of Wheat-Millet Flour Blends. Faculty of Food Science and Engineering. University of Galaty. Romania.

3. Aryee, F.N.A., I. Oduro, W. O. Ellis, dan J. J. Afuakwa. 2003. The Physicochemical Properties of Flour Sampel from The Roots of 31 Varieties of Cassava. J. Food Control Vol. 17 : 916-922.

4. Astawan, Made. 2009. Panduan Karbohidrat Terlengkap. Penerbit : Dian Rakyat. Jakarta.

5. Dina. $2012 . \quad$ Terigu. http://www.foodreview.biz/login/preview.php/terigu. Diakses : 22 April 2017.

6. Fhirman, Bhara. 2015. Arti Gandum \& Klasifikasinya. http://serealia.blogspot.co.id/2015/06/arti-gandumklasifikasinya.html. Diakses : 23 April 2017.

7. Hidayati. F. U. N. 2013. Daya Pembengkakan (Swelling Power) Campuran Tepung Kimpul (Xanthosoma Sagittifolium) Dan Tepung Terigu Terhadap Tingkat Pengembangan Dan Kesukaan Sensorik Roti Tawar. Program Studi Gizi, Fakultas Ilmu Kesehatan. Universitas Muhammadiyah Surakarta.

8. Kartiwan, Z. Hidayah, dan B. Badewi. 2007. Metode Pembuatan Adonan Untuk Meningkatkan Mutu Roti Manis Berbasis Tepung Komposit Yang Difortifikasi Rumput Laut. Jurusan Tanaman
Pangan Dan Holtikultura Politeknik Pertanian Negeri Kupang.

9. Koswara, S. 2009. Teknologi Pengolahan Roti (Seri Teknologi Pangan Populer). Produksi: eBookPangan.com.

10. Laoli, Novelius. 2017. Prediksi Impor Gandum 2017. http://industri.kontan.co.id/news/imporgandum-2017-diprediksi-tembus-879-juta-ton. Diakses : 22 April 2017.

11. Léder, I. 2004, Sorghum and Millet in Cultivated Plants, Primarily as Food Sources. [Ed. György Füleky], in Encyclopedia of Life Support Systems (EOLSS), Developed Under the Auspices of the UNESCO, Eolss Publishers, Oxford ,UK, [http://www.eolss.net].

12. Parker, R. 2003. Introduction to Food Science. Delmar Thompson Learning. United States

13. Piliang, W.G dan S. Djojosoebagio. 1996. Fisiologi Nutrisi. Edisi Kedua. UIPress. Jakarta.

14. Syamsir, Elvira. 2014. Mengendalikan Proses Fermentasi Pada Pengolahan Roti. http://ilmupangan.blogspot.co.id/2014/12/mengendali kan-proses-fermentasi-pada.html. Diakses : 27 Juli 2017.

15. Ulyarti. 1997. Mempelajari Sifat-sifat Amilografi Pada Amilosa, Amilopektin dan Campurannya. Skripsi. Fateta IPB. Bogor. 